\title{
UNDERSTANDING THE INITIAL REACTIONS OF TURKISH TWITTER USERS DURING THE COVID-19 PANDEMIC
}

\author{
Azra K. NAZLI \\ Ege University, Turkey. \\ azrakardelen.nazli@ege.edu.tr \\ http://orcid.org/0000-0003-0565-1278 \\ Celal KOCAÖMER \\ Ege University, Turkey \\ celal_kcmr@hotmail.com \\ http://orcid.org/0000-0001-9593-1761 \\ Miray BEŞBUDAK \\ Ege University, Turkey \\ miraybesbudak@gmail.com \\ http://orcid.org/0000-0002-7610-6368 \\ Nahit Erdem KÖKER \\ Ege University, Turkey \\ nahit.koker@ege.edu.tr \\ http://orcid.org/0000-0002-8622-865X
}

\begin{abstract}
This study aims to evaluate the initial reactions of Turkish social media users to the spread of the COVID-19 disease and the consequent pandemic in Turkey. The primary purpose of this investigation is to provide readers with an understanding of the transformative effects of social media on the dissemination of information and feelings, especially in moments of crisis. Content analysis approach was used for the analysis of the selected tweets with codes and themes. The themes broadly identified by the study included personal opinions, humour or sarcasm, requests and questions, emotional state, information sharing, marketing and spam. The initial reactions of Turkish Twitter users on COVID-19 related primarily to sharing personal thoughts, which included the articulation of personal opinions and the critique of the views of others. The second significant response thread involved humour and sarcasm. The third theme is requests and questions including warnings, suggestions, demands and questions.
\end{abstract}

Keywords: social media usage, crisis and risk communication, Twitter, content analysis, COVID-19

\section{COVID-19 PANDEMISI SIRASINDA TÜRK TWITTER KULLANICILARININ ILK TEPKILERINİ ANLAMAK: BİR İÇERİK ANALIZI}

\section{$\ddot{O Z Z}$}

Bu çalışma, Türkiye'deki sosyal medya kullanıcılarının COVID-19 hastalı̆̆ının yayılmasına ve bunun sonucunda ortaya çıkan pandemiye karşı ilk tepkilerini değerlendirmeyi amaçlamaktadır. Bu araştırmanın temel amacı, okuyuculara, özellikle kriz anlarında sosyal medyanın bilgi ve duyguların yayılması üzerindeki dönüştürücü etkilerini anlamalarını sağlamaktır. Seçilen tweetlerin kod ve temalarla analizinde içerik analizi yaklaşımı kullanılmıştır. Çalışma ile geniş bir şekilde tanımlanan temalar arasında kişisel görüşler, mizah veya alay, istek ve sorular, duygusal durum, bilgi paylaşımı, pazarlama ve spam yer almaktadır. Türk Twitter kullanıcılarının COVID-19 hakkındaki ilk tepkileri,

Research Article - This article was checked by iThenticate 
kişisel fikirlerin ifade edilmesi ve başkalarının görüşlerinin eleştirisini içeren kişisel düşüncelerin paylaşılmasıyla ilgilidir. İkinci önemli tepki dizisi mizah ve alay olarak saptanmış, üçüncü öne çıan tema, uyarı, öneri, talep ve soruları içeren tweetler olarak bulunmuştur.

Anahtar Kelimeler: sosyal medya kullanımı, kriz ve risk iletişimi, Twitter, içerik analizi, COVID-19

\section{INTRODUCTION}

Online social media networks have become significant channels of communication and are used extensively in almost every situation and environment. Users of all demographics utilise social media for varied reasons. These online platforms allow users to quickly access information and enable them to share their awareness with other users in real-time. These features and the ever-growing popularity and use of social media in recent years have triggered numerous studies on this relatively new method of social connectivity among people (Fraustino, Liu \& Jin, 2012; Ruggiero \& Vos, 2014; Veil, Buehner \& Palenchar, 2011). Many researchers have also probed the displays of human behaviour in social media environments from discrete perspectives.

Historically, intercultural encounters has been found to affect the spread of diseases through trade routes (Black Death, 1346), wars (Spanish Flu, 1918), and invasions (Smallpox, 1520) (Brooks, 1993, p. 1) since the time the first health-related epidemic was recorded (430-427 BCE; Hays, 2005, p. 1). Studies have also found that the long-term effects of pandemics can manifest themselves in many ways, reducing educational attainment, increasing rates of physical disability and lowering the socioeconomic status (Almond, 2006, p. 672) of affected populations. On the other hand, support for undeveloped regions (World Bank, 2018), and urbanisation ratio (Cheng \& Siankam, 2009, p. 141) can potentially be improved during a pandemic. Health crises can exert significant economic impact including the imposition of direct costs (hospitalisations), indirect costs (reduced productivity) and intangible costs (pain and reduced life quality) (Gasparini, Amicizia \& Panatto, 2012, p. 26).

It is therefore unsurprising that infectious diseases often lead to the learning of lessons for the future. For instance, the outbreak of swine flu in 2009 led to the improved surveillance of disease strains in the animal husbandry trading, and the importance of forecasting countries the travel data collated across countries to predict the paths through which pathogens could spread in geographical terms (Hosseini et. al., 2010). The global spread of swine flu also instigated research yielding the knowledge that pandemics of the future could be overcome more easily if country-based socioeconomic disparities could be reduced (Rutter et.al., 2012, p.745). Further, pandemics generate spaces for public discourse on subjects like ethics and the expertise of health care workers (Ruderman et.al., 2006, p. 1). It is historically observed that the fear caused by pandemics can make people more sensitive to health issues and new perceptions and living arrangements can emerge as a result. COVID-19, also known as the novel coronavirus, has assumed the status of a global pandemic and has exerted an immense influence on global communities. It has seriously threatened public health and has affected the emotional states of people around the world.

The classification of the COVID-19 outbreak as a global pandemic was crucial for the establishment of a common and worldwide attitude of urgency. International cooperation and coordination in efforts to combat the disease improved since COVID-19 was declared a global pandemic. A similar amelioration may be observed in international efforts to assist affected countries, the prioritisation of international medical research to develop vaccines for this disease, and in the methods of international risk communication (Mehta et al., 2020, p. 1034).

The novel coronavirus outbreak has precipitated the adoption of extraordinary steps by governments across the world to combat the spread and severity of the disease. Social isolation or distancing have been proven fundamental and indispensable as countermeasures against COVID-19. However, social distancing also takes a toll on the mental health of individuals and communities. The sense of imminent danger may cause the survival instinct. Any external factor that seems to pose an existential threat become a source of stress. A life-threatening illness may elicit acute feelings of uncertainty, anxiety and fear. These emotions may be further exacerbated by the clutter in news media, hearsay

Research Article - This article was checked by iThenticate 
information and conspiracy theories. Epidemics represent one of the major stressors that put people on high alert. Diseases have been a source of fear and have affected societies in many ways throughout human history: they have transformed social life, emphasised the importance of scientific studies and public health services, precipitated economic declines and have led to mass deaths in affected populations.

\section{LITERATURE REVIEW}

Social media platforms are used both as a means of interpersonal interaction and as sources of information from political institutions and corporations. Governments, corporations and other formal agencies now use web-based technology to instantly disseminate information to both domestic and globally dispersed audiences. Facebook, Twitter, Instagram, YouTube and other similar social media channels are pivotal in this context. Social media channels have also recently been adopted as methods of crisis communication to help people communicate with each other and cope with sudden and unexpected catastrophes or other emergencies. Since social distancing has become the norm during the COVID-19 pandemic, these social media channels have become indispensable tools, both for their ability to quickly communicate crisis-related exchanges between people and as sources of information.

\section{The Effects of Social Media on Crisis and Risk Communication}

Crisis communication functions critically in informing the public about calamities and investigates how people communicate with each other during times of emergency (Schultz, Utz \& Göritz, 2011, p. 2). Research on this subject primarily addresses correlations between crises, communication strategies and audience perceptions.

The term 'social media' indicates interactive digital platforms that allow users to access shared content and create their own content to share with and influence other users (Wright \& Hinson, 2009, p. 3). With their expansive and ever-growing user bases and their two-way communication capabilities (Bortree and Seltzer, 2009, p. 317), social media platforms facilitate information exchange between organisations and individuals and have become significant means for most exchanges related to brands, companies, and people (Taylor \& Perry, 2005, p. 211). Users can create virtual identities on social media platforms, interact with their real-life friends and establish social relationships, both online and offline, with people who have similar interests (Griffiths, 2012; Kuss \& Griffiths, 2011). Organisations can also use social media during crises circumstances to keep the public informed. For instance, vital information on the current status of the COVID-19 outbreak, content on strategies to prevent its further spread prevention and daily status updates (such as the number of deaths and cases in a region) are widely circulated by governments and non-governmental institutions via social media.

Social media has become a significant source of the latest news because traditional broadcast media channels cannot be available to all users at all times because of their limited capabilities in terms of time and place. Several studies on the topic of social media report similar outcomes of increased opportunities for the online platforms because their content can continually be updated and extended (Fraustino, Liu \& Jin 2012; Ruggiero \& Vos, 2014; Veil, Buehner \& Palenchar, 2011, p. 115). Organisations must also ensure the dissemination of reliable information because news spreads rapidly through online social media, especially in times of crisis. Thus, baseless and false information or news can easily be spread by users via social media. Organisations must continually be aware of such malicious dissemination of misinformation, fake news or baseless opinions about them and endeavour to prevent injury to their interests by also continually offering correct and timely information to the public.

Risk is both described and shaped through communication, and the various processes and methods of controlling and managing risk are defined by the term 'crisis communication', which allows for emergencies to be effectively handled through risk mitigation. For instance, individuals at high risk

Research Article - This article was checked by iThenticate 
of contracting COVID-19 must take greater precautions to protect themselves and their families. To ensure appropriate protection, they can seek information about the safeguards they should take from social media. A crisis is a situation in which a wide range of common values such as health, education, basic needs and earnings are urgently threatened. Such circumstances cause increased demands for urgent reactive actions and generate greater uncertainties regarding the full scope and consequences of the occurrence and its possible solutions (Boin et al., 2005, p. 3). In many instances, crises may be controlled by the imposition of certain restrictions on those who are most affected by them. In general, the boundaries demarcating the worst effects of crises can be determined through an analysis of similarities and differences (Olsson, 2015, p. 93). The COVID-19 crisis has compelled many parts of the world to enforce a prolonged lockdown to establish such boundaries and control the situation. In such circumstance, social media has become a major source of information and entertainment for individuals allowing them to maintain social relationships during lockdowns. Additionally, platforms such as Instagram, Facebook, Twitter, YouTube have also created avenues for meaningful dialogue between the public and organisations (Hogan \& Quan-Haase, 2010, pp. 310312). Twitter stands out particularly in this regard because of its minimalist design, a vast number of users and the consequent broad span of influence.

\section{Public Information Seeking Through Social Media}

Many institutions and individuals use communication tools to express their opinions and to influence public behaviour during a crisis. Diverse methods of crisis communication serve to inform people about developments and assist them through the crisis. Crisis communication has been actively and extensively utilised over Internet-based social media platforms in recent times to help in the management of unexpected disasters. Crises also tend to exacerbate extant infrastructural and socioeconomic difficulties and thus create risks and threats that can take on national, global or even cultural dimensions (Boin, Rhinard \& Ekengren, 2014; Falkheimer, 2013; Olsson, 2015). The rapid transmission of information such as news content, images and videos with the help of mobile phones and digital technologies has brought about a fundamental change in how users interact with media. Today, every oral and textual articulation may be supported by audio or visual elements through the accompaniment of video or image and this multimedia effect influences the manner in which information is consumed. The public is now increasingly active in the search for information and online social media platforms have emerged as significant modes of information dissemination (Gottfried \& Shearer, 2016; Kim, Sin, \& Tsai, 2014). Social media sites offer all users a space to initiate and to engage in dialogues and serve as fast, easy and inexpensive channels of information dissemination. Thus, platforms such as Twitter, Instagram and Facebook have become immensely popular communication tools, especially in situations when face-to-face communication is not feasible.

Social media usage facilitates the objectives of chatting, passing time and accessing information sources and Twitter, one of the most commonly used platforms, is primarily used to share data, obtain information, communicate, socialise and entertain. Describing the increasing use of social media among individuals as an addiction, Beyens, Frison and Eggermont (2016, p. 1) contend that such dependencies are nurtured by the human desire to satisfy social needs, the human compulsion to establish and maintain stable interpersonal relationships and the human wish to attain popularity. The fear of missing out (FOMO) is another human attribute that affects the use of social media. The acronym FOMO was included in the Oxford Dictionary in 2013, and is defined as the fear of missing improvements and sharing (Przybylski et al., 2013, p. 1841). Social media participation may be attractive to individuals because they desire to know updating news about social events. This compelling demand for pleasant collective experiences without fear of social exclusion (Blackwell, 2017, p. 69) is triggered by the concern that others miss exciting or interesting (Oxford Dictionary, 2020). Such apprehensions cause people to check social media accounts more frequently. Social media is therefore pivotal in eliminating the FOMO pertaining to developing situations, a fear that is fundamentally triggered by the human need to belong to an in-group or a community of people.

Research Article - This article was checked by iThenticate 
The alarming spread of COVID-19 and its consequent classification as a global pandemic precipitated extensive measures taken by governments around the world to quarantine affected populations. The imposition of temporary restrictions on certain individual freedoms is intended for the greater benefit of society; however, such quarantine practices completely transform the daily routines of individual citizens and restrict face-to-face communication. The just and timely implementation of quarantines is vital for the maintenance of social peace and for the preservation of the mental health of individuals. Quarantines can evoke negative feelings associated with separation from loved ones, loss of independence and loss of control; in addition, prolonged uncertainty and boredom may also exercise dramatic effects on the mental health of individuals. Therefore, support programmes that intervene in a timely manner at both the individual and social levels become crucial in circumstances in which increased social distancing can affect mental health. The social distancing norms that are currently being enforced across the globe as measures to control COVID-19 also amount to a kind of enforced isolation. Although social distancing norms do not generally mandate absolute isolation, people are advised to minimise contact with others to limit their exposure to the virus. Social isolation is a state of alienation in which social connections are limited or are completely absent. In such a situation, individuals can become estranged both from the public agenda and from their daily life activities. Alienation may also be interpreted as the inability of the human adaptation mechanism to keep up with the rapid developments of the digital world. At the same time, people are compelled to utilise digital networks as communication tools for the achievement of their daily objectives and to bridge social gaps to avoid a complete rupture from the real world and from their communities. This adaptation process may evoke feelings of loneliness and cause stress. Loneliness is a subjective feeling of distress triggered by the sense that one's social connections are inadequate or unsatisfactory. Studies have evidenced that excessive Internet use is associated with the emotional state of loneliness (Kraut et al., 1998, pp. 1017-1031). Scholars have also reported that extreme Internet use results in other negative consequences such as decreased educational performance, less time for offline social activities and weaker interpersonal relationships (Sanders et al., 2000, pp. 237-242).

\section{Self-Expression and Social Sharing of Emotions on Twitter}

People may feel more satisfied when they share positive emotions on social media and find validation from other individuals and channels on their network. This satisfaction relates to feedback, both in terms of quantity and quality. Experiencing emotions is an essential part of human existence (Barrett, 2006, p. 20). The emotional experience begins as an internal process when it first appears, but the need to share emotions socially with others leads individuals (Rimé, 2009, p. 62). The social sharing of emotions may be described as the verbal expression of feelings by one individual to others (Rimé et al., 2011, p. 147). People primarily share emotions socially to convey their feelings to others through social interactions, to manage their emotions and to engage in interpersonal communication through emotional expression (Zaki \& Williams, 2013, p. 805). Emotions generally affect a person from the moment they are first felt and direct them to share these feelings with others, especially with those who they deem strong and supportive. Such sharing supports both self-directed (expression of self-soothing emotions) and other-oriented (pending support and confirmation) mechanisms and help people improve their emotional balance (Rimé, 2009, p. 65).

The social sharing of emotions is limited by a medium's characteristics and capabilities because such sharing is often prepared for a single subject or for the achievement of a relationally proximate goal. In other words, the expression of emotions related to an event reaches an intended target on social media with the help of the relevant channel and related content (Bazarova et al., 2012, p. 123). For example, Twitter users can produce network-visible content such as tweets, status updates, and posts on others' timelines. Through Twitter, people can share feelings and ideas about a particular subject with larger and diverse groups. Using a specific syntax, users on Twitter can forward messages ('retweet') from other users, respond to other users or mention other users on their posts. This style of

Research Article - This article was checked by iThenticate 
sharing has been proven to motivate people to regulate their emotions through interpersonal interactions (Bazarova \& Choi, 2014, p. 4).

\section{METHODOLOGY}

\section{Purpose and Significance}

The COVID-19 pandemic has affected most of the world including Turkey. It has become one of the most discussed topics on digital social media platforms. Twitter, one such platform, is a microblogging site regularly used by subscribers to share information and ideas, especially during times of crisis. This study intended primarily to examine the content of tweets posted during this ongoing health crisis and to evaluate the initial reactions of Turkish Twitter users to the spread of the COVID-19 virus in Turkey. In so doing, the study hoped to glean insights into feelings evoked in people by health crises.

This study was therefore intended to serve as a means of identifying and observing specific themes in tweets and to facilitate the understanding of the changes in the perception of the COVID-19 virus as articulated by Twitter users since the virus first became public knowledge. To fulfil this objective, the present investigation aimed to observe themes in tweets posted daily. The following research questions were probed:

RQ1: What were the initial reactions of Turkish Twitter users to the COVID-19 pandemic?

RQ2: What emotions were dominant in the tweets posted by Turkish Twitter during the COVID-19 pandemic?

RQ3: How did initial reactions change from day to day since the announcement of the first case?

Unlike traditional media, social media platforms accord their users the opportunity to create and to share their own original content. Pandemics represent extraordinary periods, both at the social and at the individual levels. Emotions such as uncertainty, anxiety, fear and panic usually prevail during such periods and people constantly seek to obtain updated information on their environment and on the steps being taken to combat the health crisis. Individuals can also share their personal knowledge and experiences about the situation. Therefore, sustained observation of the posts uploaded by social media users in such periods can provide crucial information about the users and about the society they inhabit. In addition, a review of the extant literature evinces that social media-oriented studies are necessary for the comprehension of the types of posts shared about COVID-19. Therefore, this study intended to contribute to the extant scholarship by offering insights into individual coping mechanisms in pandemic circumstances.

\section{Research Design}

The methodology of the case study was preferred and was considered most suitable as the research design for the investigation of the research questions this study sought to answer. Case studies aim to reveal outcomes related to specific situations (Yıldırım \& Şimşek, 2016, p. 73) involving a single person, a programme, a group, an institution, a society or a special policy (Merriam, 2013, p. 40). This case study addressed the ongoing COVID-19 pandemic.

\section{Research Sample and Data Collection}

Active Twitter users utilise the platform to opine on societal concerns and times of crisis (Mills, Chen, Lee \& Rao, 2009, p. 4; Hughes \& Palen, 2009, p. 249). This social space provides a real-time framework for the succinct articulation of what people think and do (Sreenivasan, Lee \& Goh, 2011, p. 123). Twitter was chosen as the social media platform to be studied because of the kind of insights it could offer. In addition, researchers in various fields of the social sciences tend to prefer social media platforms such as Twitter because they yield large caches of data created by their users (Rafail, 2018, p. 195). However, data collection may be constrained by diverse factors such as the computer program used, Twitter data sharing policy, and so on (Zafar, Bhattacharya, Ganguly, Gummadi \&

Research Article - This article was checked by iThenticate 
Ghosh, 2015, p. 13; Rafail, 2018, p. 196; Twitter FQA, 2020). These limitations may hinder researchers from analysing all data and may force them to work with specific samples. One of the most frequently used sampling methods in studies involving Twitter is the collection of tweets via hashtags in accordance with the Twitter API policy (Gerlitz \& Reider, 2013; Bruns \& Stieglitz, 2012, pp. 165-166; Burgess \& Bruns, 2012). Using this method, this study randomly selected 70,000 tweets using the $\mathrm{R}$ programme with identified hashtags that were pertinent to the scope of the research. This data was collected from Twitter over 7 days beginning on 11 March 2020, when Turkey announced its first positive COVID-19 case. The top trending hashtags related to the novel coronavirus pandemic were used for the collection of data. These hashtags were: \#coronavirusu, \#coronavirus, \#ciddiyealın, \#evindekaltürkiye, \#coranaturkiye, \#coronatuerkiye ve and \#coronaturkiye. Accordingly, 10,000 daily and 70,000 aggregate tweets were listed and prepared for analysis in congruence with Twitter's data sharing policy and the permissions made possible by the utilised programme. A total of 10500 tweets were selected using the simple random sampling method to satisfy the following criteria: enabling the manual content analysis of 70,000 collected tweets, meeting the condition of equal daily totals of posted tweets; and to uphold the likelihood of all tweets being included in the sample (Ural \& Kilıç, 2013, p. 36; Aziz, 2014, p. 51).

Document analysis was chosen as the most appropriate data assessment tool since every tweet about the coronavirus was deemed to be a document containing the feelings and ideas of Twitter users on the coronavirus outbreak in Turkey. Various studies on Twitter have observed that the research period of a week is sufficient (Kushin, 2010; Melek, 2015). For this reason, the data used in this study was collected over a period of 7 days, between 11 and 17 March 2020.

\section{Data Analysis Procedure}

Content analysis is often preferred for the evaluation of data by studies that examine documents. The investigation utilised quantitative text analysis as well as qualitative and quantitative content analysis methods. The 70,000 tweets collected for the study were first subjected to various quantitative text analysis methods with the help of a computer program. Subsequently, 10,500 tweets were randomly selected and the manual content analysis was performed on these tweets. The tweets were equally distributed and 1,500 tweets were taken from each day of the study period. Of the 10,500 tweets that were ultimately compiled, 59 contained only links and were thus excluded from the study because links were not opened during the analysis. The remaining 10,441 tweets were finally analysed.

Categories and coding schemes can be developed in qualitative content analysis using three different sources: data, related previous studies and theories (Wildemuth, 2009, p. 311). The coding scheme for this study was created using the collected data and with reference to related previous investigations. Accordingly, various extant studies have contributed to the general framework of the coding scheme used in the present examination (Chew \& Eysenbach, 2010; Liu \& Kim, 2011; Stellefson et al, 2014; Wang \& Zhuang, 2017, Sung \& Hwang, 2014). Then, 250 randomly selected tweets were analysed by three researchers in order to design a coding scheme that complied with the general framework of this study. Thus, the first draft coding scheme was created. This first draft was evaluated at the second stage on 250 different arbitrarily selected tweets, and new codes were added to the first draft coding scheme if any insufficiencies were identified. A second coding scheme was thus created with the addition of new codes. The coding scheme was continually revisited and revised in this manner until the researchers were certain that all the tweets about COVID-19 were accounted for and accommodated by the coding scheme. The codes that were obtained were categorised into themes after the coding scheme was created. During the manual evaluation, the researchers observed that a tweet could be positioned under more than one code. The potential of such multiplicity of positioning possibilities to create problems in content analysis became obvious because of the large size of the dataset. Thus, dominant codes were identified, and each analysed tweet was placed under a dominant code in terms of its primary signification. The sections that follow utilise descriptive tables to detail the codes and themes used for this study.

Research Article - This article was checked by iThenticate 


\section{Reliability and Validity}

Some measures recommended in scientific research were applied to ensure the reliability and validity of the current study. One such measure to ensure reliability and validity is the diversity of researchers. In content analysis, the coding of the dataset by different coders is a diversification method that contributes to the validity and verification of data (Patton, 1999, p. 1193). Content analysis should be designed for coding by more than one coder (Lombard, Snyder-Duch \& Bracken, 2002, p. 600; Yıldırım \& Şimşek, 2016, p. 275). The present investigation employed three different coders to analyse the data.

The determination of inter-coder reliability is another scientifically recommended measure. Intercoder reliability is a critical component of content analysis, and the interpretation of data cannot be considered valid if reliability is not proven (Lombard et al, 2002, p. 589). Random tweets were selected and the reliability of the study was tested through a pilot test. The evaluation of inter-coder reliability requires $10 \%$ of the entire sample, not amounting to less than 50 units; however, more than 300 samples are rarely required (Lombard et al, 2002, p. 600). For this reason, the same 1,050 tweets utilised for the pilot test were coded by three different coders. Each coder was given 15 days to encode 1,050 tweets.

The Kappa test is often used in content analyses to determine reliability. However, the commonly used Cohen Kappa test is valid only for two different coders (Fleiss, 1971). Fleiss' Kappa test can be used in instances with more than two encoders (Laerd Statistics, 2019). Therefore, Fleiss' Kappa test was executed using the SPSS programme to ascertain the inter-coder reliability of the current research. The inter-coder agreement between themes was examined during the application of Fleiss' Kappa test. In cases of disagreements among the three coders, themes and codes were evaluated if two of the three individuals presented an identical decision for the same theme or code. If the themes and codes selected by all the coders for a tweet were distinctive, the fourth author was called to objectively evaluate the tweets and to settle disagreements. After the coding scheme was finalised, the reliability values were determined for different numbers of tweets in the first stages. It was observed that the determined values were below 0.50. At the end of an additional training and evaluation process, a 1,000-tweet pilot test evaluation was initiated. As a result of the pilot test, the reliability value of the three coders was found to be 0.747 . It is usually held that values between 0.610.80 indicate a conducive agreement in the classification of Kappa values (Landis \& Koch, 1977, p. 165). Yıldırım and Şimşek (2016, p. 247) maintain that a minimum value of 0.70 is required for reliability. After the inter-coder reliability was established, the three coders respectively and separately coded 3,150, 3,150 and 3,200 tweets in the space of a month, amounting to the total of 10,500 tweets. Given the scope of the study, the dominant codes were scrutinised to calculate the inter-coder reliability. Other measures besides the steps described above were also taken to ensure validity and reliability. These included the use of semi-statistics, transparency, methodological diversification, and the use of appropriate tables (Whittemore, Chase \& Mandle, 2001).

\section{FINDINGS}

\section{Quantitative Text Analysis Findings}

Table 1 shows the most used hashtags among 70,000 randomly selected tweets between 11 and 17 March 2020. The hashtag \#coronaturkiye was the most utilised $(n=13,670)$ followed by \#coronavirus, \#coronatuerkiye, \#coronavirusu, \#ciddiyealın (\#takeitseriously), \#evindekaltürkiye (\#stayathometurkey) and \#coranaturkiye. These hashtags were related to COVID-19 and requests made by Turkish Twitter users. 
Table 1: The frequencies and percentages of hashtags

$\begin{array}{lll}\text { \# hashtag } & \mathrm{N} & \% \\ \text { coronaturkiye } & 13,670 & 10.31 \\ \text { coronavirus } & 13,011 & 9.81 \\ \text { coronatuerkiye } & 10,895 & 8.21 \\ \text { coronavirusu } & 10,462 & 7.89 \\ \text { ciddiyealın } & 10,032 & 7.56 \\ \text { evindekaltürkiye } & 8,399 & 6.33 \\ \text { coranaturkiye } & 5,679 & 4.28\end{array}$

Table 2 presents the 12 most commonly used hashtags that accompanied corona hashtags. \#cologne was the most recurrent hashtag $(\mathrm{n}=2,032)$ accompanying the corona hashtags. Other frequently used hashtags were \#curfew, \#blowthevirusbykoca (Fahrettin Koca is Turkey's health minister), \#sorrypositive and \#theschoolsareonholiday. These hashtags were related to precautions taken to prevent the spread of COVID-19, the demonstration of gratitude towards the health minister and the expression of sympathy for those who tested positive.

Table 2: The top 12 most frequently used hashtags along with corona hashtags

$\begin{array}{lll}\text { \# hashtag } & \mathrm{n} & \% \\ \text { Kolonya(\#cologne) } & 202 & 1.53 \\ \text { Sokağacıkmayasağ1(\#curfew) } & 886 & 0.67 \\ \text { Virüsekocadarbesi(\#blowthevirusbykoca) } & 711 & 0.54 \\ \text { maalesefpozitif(\#sorrypositive) } & 532 & 0.40 \\ \text { okullartatil(\#theschoolsareonholiday) } & 503 & 0.38 \\ \text { Sondakika(\#breakingnews) } & 487 & 0.37 \\ \text { asteroid2020 (\#asteroid2020) } & 461 & 0.35 \\ \text { Kolonyalobisi(\#colognelobby) } & 414 & 0.31 \\ \text { Mgros (\#migros) } & 351 & 0.26 \\ \text { Elleriniylka (\#washyourhands) } & 242 & 0.18 \\ \text { Evdekeyfimyerinde(\#enjoyyourselfathome) } & 241 & 0.18 \\ \text { Olağanüstügünler (\#extraordinarydays) } & 205 & 0.15\end{array}$

\section{Content Analysis Findings}

Figure 1 illustrates the themes found by the manual content analysis. These themes included personal opinion $(\mathrm{n}=2,731,26 \%)$, humour and sarcasm $(\mathrm{n}=2,391,22.8 \%)$, requests and questions $(\mathrm{n}=$ $2,101,20 \%)$, emotional state $(\mathrm{n}=1,597,15.2 \%)$, information sharing $(\mathrm{n}=1,243,11.8 \%)$, spam $(\mathrm{n}=$ $346,3.3 \%)$ and marketing $(\mathrm{n}=32,0.3 \%)$. The codes that comprise these themes are detailed below.

Figure 1: Themes of COVID-19 tweets

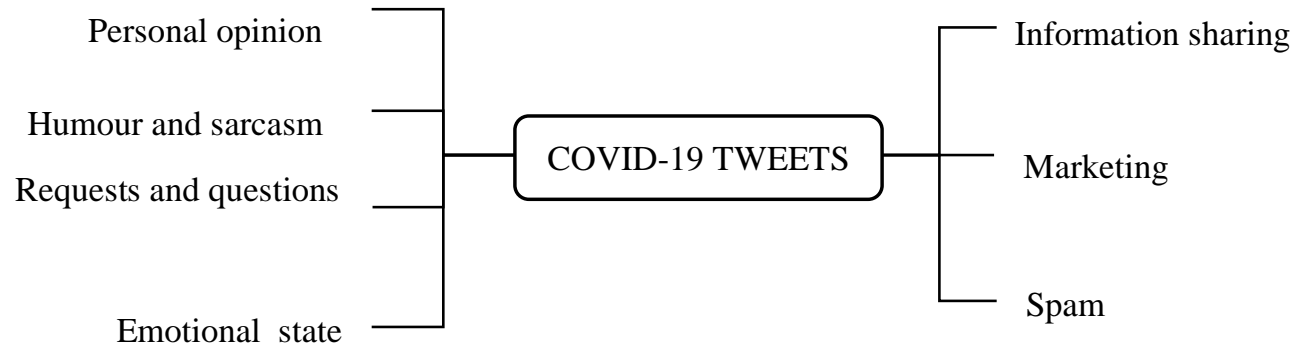

Twitter users often share tweets to express themselves (Stieglitz \& Dang-Xuan, 2013) and regularly post tweets to articulate their opinions during natural disasters or crises (Rajdev \& Lee, 2015). This 
study added the theme of personal opinion because Twitter users frequently shared personal opinions about COVID-19.

The most common theme for the tweets posted by Turkish Twitter found to be personal opinion $(\mathrm{n}=$ $2,731,26 \%)$. Tweets encoded within this theme included ones shared by Twitter users to articulate their views about the virus/situation/news (Chew \& Eysenbach, 2010, p. 2). A tweet was coded into the personal opinion theme if it expressed an opinion about COVID-19. The most commonly used codes in this theme were idea $(n=697)$, criticising society $(n=463)$, personal experiences $(n=340)$, beliefs $(n=267)$, criticising the government $(n=216)$ and criticising authority $(n=153)$ (Table 3$)$. Put differently, people mostly voiced their attitudes and beliefs, criticised people and shared their personal experiences about COVID-19 with other people.

Table 3: Personal opinion related tweet frequencies and percentages

$\begin{array}{llll}\text { Themes } & \text { Codes } & \mathrm{n} & \% \dagger \\ \text { Personal Opinion } & \text { Idea } & 697 & 6.6 \\ & \text { Criticising society } & 463 & 4.4 \\ & \text { Personal experiences } & 340 & 3.2 \\ & \text { Beliefs } & 267 & 2.5 \\ & \text { Criticising government } & 216 & 2.1 \\ & \text { Criticising authority } & 153 & 1.5 \\ \text { Comparison } & 123 & 1.2 \\ \text { Conspiracy theory } & 112 & 1.1 \\ \text { Support } & 92 & 0.9 \\ \text { Trust } & 81 & 0.8 \\ \text { Distrust } & 53 & 0.5 \\ & \text { Otherisation } & 47 & 0.4 \\ \text { Racism } & 40 & 0.4 \\ \text { Contempt } & 25 & 0.2 \\ \text { Threat } & 22 & 0.2\end{array}$

$\dagger$ The percentage computed in comparison to all codes.

Humour is ubiquitous and universal (Polimeni \& Reiss, 2006, p. 348) and is essentially a communicative activity (Lynch, 2002, p. 423). The Internet plays an important role in the rapid spread of humour (Shifman, 2007; Shifman, Levy \& Thelwall, 2014). Since Twitter facilitates the spread of humour as an Internet-based platform, humour was also considered as a theme for this study, and sarcasm was also included since some of the tweets were both sarcastic and humorous.

The second most common theme for the tweets posted by Turkish Twitter users between 11 and 17 March was humour and sarcasm $(n=2,391,22.8 \%)$. Tweets encoded within this theme were ones associated with comic entertainment, parody and irony. A tweet was coded into this theme if it included a humorous or sarcastic comment about COVID-19 via text, image or video. The most frequent codes for this theme were irony $(n=1,166)$, jokes $(n=857)$ and parodies $(n=368)$ (Table 4). It is noteworthy in this context that irony and jokes represented the codes that were most utilised overall.

Table 4: Humour and sarcasm related tweet frequencies and percentages

$\begin{array}{llll}\text { Themes } & \text { Codes } & \mathrm{n} & \% \dagger \\ \text { Humour and sarcasm } & \text { Irony } & 1,166 & 11.1 \\ & \text { Jokes } & 857 & 8.2 \\ & \text { Parodies } & 368 & 3.5 \\ & \text { Total } & 2,391 & 22.8\end{array}$

$\dagger$ The percentage computed in comparison to all codes.

The Internet and social media platforms substantially enable dialogue and interaction (Taylor, Kent \& White, 2001; Bortree \& Seltzer, 2009; Rybalko \& Seltzer, 2010). Thanks to social media platforms, 
the potential for two-way dialogue and interaction among people, governments and organisations has also increased (Bortree \& Seltzer, 2009). Therefore, it was not surprising that people made requests and queried other users and the government through social media channels during the COVID-19 pandemic.

Requests and questions were also posited as a theme for the present study and it was calculated to be the third most common theme in the tweets posted by Turkish Twitter users $(\mathrm{n}=2,101,20 \%)$. Any tweet asking a COVID-19-related question or requesting something from a community, authority or the government was coded into this theme. The most commonly used codes in this theme included warnings $(n=619)$, suggestions $(n=479)$, demands from the community $(n=465)$, questions $(n=$ $233)$ and demands from the government $(n=230)$. The frequency of the other codes under this theme was relatively lower (Table 5).

Table 5: Request and question-related tweet frequencies and percentages

\begin{tabular}{|c|c|c|c|}
\hline Themes & Codes & $\mathrm{n}$ & $\% \dagger$ \\
\hline \multirow{8}{*}{$\begin{array}{l}\text { Requests and } \\
\text { questions }\end{array}$} & Warnings & 619 & 5.9 \\
\hline & Suggestions & 479 & 4.6 \\
\hline & Demand from society & 465 & 4.4 \\
\hline & Questions & 233 & 2.2 \\
\hline & Demands from government & 230 & 2.2 \\
\hline & Demands from authority & 50 & 0.5 \\
\hline & Demands from all & 25 & 0.2 \\
\hline & Total & 2,101 & 20 \\
\hline
\end{tabular}

$\uparrow$ The percentage computed in comparison to all codes.

People experience varying emotions such as anger, fear, surprise, and worry in crisis situations (Choi \& Lin, 2009). Social media has emerged as an important platform for the sharing of such emotions. Social media posts often reflect the emotional states of subscribers (Bollen, Mao \& Pepe, 2011) and this theme was thus added because many Twitter users shared their feelings through tweets about COVID-19.

The fourth most common theme for the tweets posted by Turkish Twitter users between 11 and 17 March concerned their emotional states $(n=1,597,15.2 \%)$. Tweets encoded within this theme expressed emotions such as panic, curiosity, fear, hope, imprecation, gratitude, concern, aggression, uncertainty, disinterest, sadness, disappointment and being united against COVID-19. Any tweet incorporating a comment about these emotions was coded into this theme. The most commonly used codes for this theme were aggression $(n=330)$, gratitude $(n=240)$, concern $(n=200)$ and hope $(n=$ 147) (Table 6). In general, the codes under this theme evinced a balanced distribution.

Table 6: Emotional state-related tweet frequencies and percentages

\begin{tabular}{llll} 
Themes & Codes & $\mathrm{n}$ & $\% \dagger$ \\
Emotional State & Aggression & 330 & 3.1 \\
& Gratitude & 240 & 2.3 \\
& Concern & 200 & 1.9 \\
& Hope & 147 & 1.4 \\
\hline Disinterest & 106 & 1.0 \\
\hline Disappointment & 105 & 1.0 \\
\hline Fear & 104 & 1.0 \\
\hline Being unity & 99 & 0.9 \\
Panic & 92 & 0.9 \\
Sadness & 67 & 0.6 \\
\hline Uncertainty & 47 & 0.4 \\
\hline Imprecation & 30 & 0.3 \\
Curiosity & 30 & 0.3 \\
\hline Total & 1,597 & 15.2
\end{tabular}

$\uparrow$ The percentage computed in comparison to all codes.

Research Article - This article was checked by iThenticate 
People desire the maximisation of access to information in times of crisis and often use social media to share and obtain information (Procopio \& Procopio, 2007; Austin, Fisher Liu \& Jin, 2012). Information seeking, obtaining timely information and getting unfiltered information are some of the reasons why people take to social media during catastrophes (Fraustino et al, 2012). In the case of COVID-19, people used Twitter to gather and share information.

Thus, information was included as a theme and was assessed to be the fifth most common theme $(\mathrm{n}=$ $1,243,11.8 \%$ ) for the tweets posted by Turkish Twitter users. This theme included the exchange of information or news and any tweet containing a tweet relevant and newsworthy information about COVID-19 was coded into this theme. These information sharing tweets comprised mostly of photos, videos or links to webpages and they could be further shared by organisations or other Twitter users. The most used codes for this theme were announcements $(n=313)$, breaking news $(n=291)$, case updates $(n=284)$ and disease prevention $(n=112)$. The frequencies of other codes under this theme were found to be considerably lower (Table 7).

Table 7: Information sharing related tweet frequencies and percentages

\begin{tabular}{|c|c|c|c|}
\hline $\begin{array}{l}\text { Themes } \\
\text { Information sharing }\end{array}$ & Codes & $\mathrm{n}$ & $\% \dagger$ \\
\hline \multirow[t]{14}{*}{ Information sharing } & Announcements & 313 & 3.0 \\
\hline & Breaking news & 291 & 2.8 \\
\hline & Case updates & 284 & 2.7 \\
\hline & Disease prevention & 112 & 1.1 \\
\hline & Infection control & 46 & 0.4 \\
\hline & Misinformation & 43 & 0.4 \\
\hline & Rumour & 38 & 0.4 \\
\hline & Economic consequences & 33 & 0.3 \\
\hline & New evidence & 31 & 0.3 \\
\hline & Absurd news & 22 & 0.2 \\
\hline & Healthcare services & 11 & 0.1 \\
\hline & Scientific discovery & 11 & 0.1 \\
\hline & Emotional news & 8 & 0.1 \\
\hline & Total & 1,243 & 11.8 \\
\hline
\end{tabular}

The sixth theme identified as the most popular in the tweets of Turkish Twitter was spam $(n=346$, $3.3 \%$ ). Tweets compiled under this theme generally used hashtags about COVID-19 but did not contain relevant information or opinions about the virus outbreak. These tweets primarily aimed for popularity by using the trending hashtag. In other words, tweets encoded within this theme were unrelated to COVID-19. The codes identified under this theme were irrelevant tweet $(n=317)$ and foreign language $(\mathrm{n}=29,0.3 \%)$ (Table 8$)$.

Table 8: Spam related tweet frequencies and percentages

$\begin{array}{llll}\text { Themes } & \text { Codes } & \mathrm{n} & \% \dagger \\ \text { Spam } & \text { Irrelevant tweet } & 317 & 3.0 \\ & \text { Foreign language } & 29 & 0.3 \\ & \text { Total } & 346 & 3.3\end{array}$

$\dagger$ The percentage computed in comparison to all codes.

Social media platforms are cost-effective for the promotion of brands and for the execution of other marketing activities (Kirtiş \& Karahan, 2011; Parveen, Jaafar \& Ainin, 2015; Han \& Kim, 2016). Numerous business enterprises were found to utilise Twitter to endorse brands or products related to COVID-19. Therefore, the theme of marketing was added to this study but was found to be the least common for the tweets posted by Turkish Twitter users $(\mathrm{n}=32,0.3 \%)$. Any tweet incorporating corporate or personal advertising for a COVID-19-related product was coded into this theme. Such

Research Article - This article was checked by iThenticate 
tweets were shared by both organisations and individual Twitter users. The codes used for this theme were advertising $(n=22,0.2 \%)$ and personal selling $(n=10,0.1 \%)$ (Table 9).

Table 9: Marketing related tweet frequencies and percentages

$\begin{array}{llll}\text { Themes } & \text { Codes } & \mathrm{n} & \% \dagger \\ \text { Marketing } & \text { Advertising } & 22 & 0.2 \\ & \text { Personal selling } & 10 & 0.1 \\ & \text { Total } & 32 & 0.3\end{array}$

$\uparrow$ The percentage computed in comparison to all codes.

The COVID-19-related tweets were collected between 11 March and 17 March 2020 and categorised into the themes mentioned above. They were then analysed to calculate the daily thematic changes in the compiled tweets. Table 10 demonstrates the daily distribution of the themes on the dates that comprised the study. The usage frequency and thematic rates were altered since the announcement of the first COVID-19 case in Turkey. The most common themes on 11 March involved personal opinion (32\%), humour and sarcasm (30.5\%), and emotional state (14.1\%). On 12 March, information-related tweets spiked and the information sharing theme overtook the emotional state theme in terms of the number of tweets. The most common themes on 12 March were personal opinion (27.5\%), humour and sarcasm (26.3\%) and information sharing (15.4\%). The most common themes on 13 March were humour and sarcasm (33.7\%), personal opinion (20.3\%) and information sharing (16.7\%). On 14 March, humour and sarcasm (29.4\%), personal opinion (23.7\%) and information sharing (17\%) were most commonly observed, and humour and sarcasm related tweets also topped the themes on 13 and 14 March. On 15 March, the request and question theme featured for the first time among the top three themes. The most common themes on 15 March were personal opinion (25.8\%), humour and sarcasm $(21.3 \%)$ and request \& question (18.3\%). Request and question-related tweets peaked after 15 March. On 16 March, the most common themes were requests and questions (32.6\%), personal opinion (26.7\%) and emotional state (17.9). Finally, the most common themes on 17 March were requests and questions (37.6\%), personal opinion (26.5\%) and emotional state (19.5\%). The least common themes for all seven days were spam and marketing.

In sum, Table 10 evinces that Turkish Twitter users primarily shared entertaining, ironic and parodic tweets in the first five days after the first COVID-19 case was announced. However, as the risks posed by COVID-19 gradually dawned upon the users, the humour and sarcasm related tweets dropped significantly. The number of informational tweets (such as COVID-19 case updates, breaking news, disease prevention and government statements) saw an increase a day after the announcement of the first positive case in Turkey. However, the last two days of the study period saw a decrease in the sharing of newsworthy information. A brief look at the personal opinion theme shows that it featured consistently among the most common themes throughout the study period. A similar statement can be made for the emotional state theme. Although there was no major change observed, the frequency of emotional state-related tweets saw an increase in the last two days. As concerns about the dangers of COVID-19 appeared to grow, tweets that included feelings such as panic, fear, concern and aggression saw an increase in terms of the number of posts. A similar distribution can be observed for the requests and questions theme for the first four days. There was an increase in tweets on this theme on the fifth day, and tweets related to this particular theme peaked on the sixth and seventh days. Since hashtags such as \#ciddiyealın (takeitseriously), \#evindekaltürkiye (stayhometurkey) and \#elleriniyıka (washyourhands) were trending, they may have influenced the increase in the number of tweets related to requests and questions. Finally, the marketing and spam themes saw no significant changes over the course of the seven-day study period.

Research Article - This article was checked by iThenticate 
Table 10: Daily changes in theme frequencies and percentages

\begin{tabular}{|c|c|c|c|c|c|c|c|}
\hline Days $\dagger$ & $\begin{array}{r}11 \\
\text { March }\end{array}$ & $\begin{array}{r}12 \\
\text { Marc } \\
\mathrm{h}\end{array}$ & $\begin{array}{r}13 \\
\text { March }\end{array}$ & 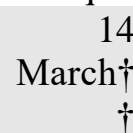 & $\begin{array}{r}15 \\
\text { March } \dagger \dagger\end{array}$ & $\begin{array}{r}16 \\
\text { March } \dagger \dagger\end{array}$ & $\begin{array}{r}17 \\
\text { March }\end{array}$ \\
\hline $\begin{array}{l}\text { Humour } \\
\text { and } \\
\text { sarcasm }\end{array}$ & $\begin{array}{r}457 \\
30.5 \%\end{array}$ & $\begin{array}{r}394 \\
26.3 \\
\%\end{array}$ & $\begin{array}{r}506 \\
33.7 \%\end{array}$ & $\begin{array}{r}441 \\
29.4 \%\end{array}$ & $\begin{array}{r}319 \\
21.3 \%\end{array}$ & $\begin{array}{r}144 \\
9.6 \%\end{array}$ & $\begin{array}{r}132 \\
8.8 \%\end{array}$ \\
\hline $\begin{array}{l}\text { Informatio } \\
\mathrm{n} \text { sharing }\end{array}$ & $\begin{array}{r}124 \\
8.3 \%\end{array}$ & $\begin{array}{r}231 \\
15.4 \\
\%\end{array}$ & $\begin{array}{r}250 \\
16.7 \%\end{array}$ & $\begin{array}{r}255 \\
17.0 \%\end{array}$ & $\begin{array}{r}184 \\
12.3 \%\end{array}$ & $\begin{array}{r}114 \\
7.6 \%\end{array}$ & $\begin{array}{r}81 \\
5.4 \%\end{array}$ \\
\hline $\begin{array}{l}\text { Personal } \\
\text { opinion }\end{array}$ & $\begin{array}{r}480 \\
32.0 \%\end{array}$ & $\begin{array}{r}413 \\
27.5 \\
\%\end{array}$ & $\begin{array}{r}304 \\
20.3 \%\end{array}$ & $\begin{array}{r}356 \\
23.7 \%\end{array}$ & $\begin{array}{r}387 \\
25.8 \%\end{array}$ & $\begin{array}{r}400 \\
26.7 \%\end{array}$ & $\begin{array}{r}398 \\
26.5 \%\end{array}$ \\
\hline $\begin{array}{l}\text { Emotional } \\
\text { state }\end{array}$ & $\begin{array}{r}211 \\
14.1 \%\end{array}$ & $\begin{array}{r}194 \\
12.9 \\
\%\end{array}$ & $\begin{array}{r}214 \\
14.3 \%\end{array}$ & $\begin{array}{r}188 \\
12.5 \%\end{array}$ & $\begin{array}{r}225 \\
15.0 \%\end{array}$ & $\begin{array}{r}269 \\
17.9 \%\end{array}$ & $\begin{array}{r}293 \\
19.5 \%\end{array}$ \\
\hline $\begin{array}{l}\text { Requests } \\
\text { and } \\
\text { questions }\end{array}$ & $\begin{array}{r}182 \\
12.1 \%\end{array}$ & $\begin{array}{r}212 \\
14.1 \\
\%\end{array}$ & $\begin{array}{r}187 \\
12.5 \%\end{array}$ & $\begin{array}{r}190 \\
12.7 \%\end{array}$ & $\begin{array}{r}275 \\
18.3 \%\end{array}$ & $\begin{array}{r}489 \\
32.6 \%\end{array}$ & $\begin{array}{r}564 \\
37.6 \%\end{array}$ \\
\hline Marketing & $\begin{array}{r}4 \\
0.3 \%\end{array}$ & $\begin{array}{r}5 \\
0.3 \%\end{array}$ & $\begin{array}{r}8 \\
0.5 \%\end{array}$ & $\begin{array}{r}11 \\
0.7 \%\end{array}$ & $\begin{array}{r}3 \\
0.2 \%\end{array}$ & $\begin{array}{r}0 \\
0.0 \%\end{array}$ & $\begin{array}{r}1 \\
0.1 \%\end{array}$ \\
\hline Spam & $\begin{array}{r}42 \\
2.8 \%\end{array}$ & $\begin{array}{r}51 \\
3.4 \%\end{array}$ & $\begin{array}{r}31 \\
2.1 \%\end{array}$ & $\begin{array}{r}57 \\
3.8 \%\end{array}$ & $\begin{array}{r}86 \\
5.7 \%\end{array}$ & $\begin{array}{r}48 \\
3.2 \%\end{array}$ & $\begin{array}{r}31 \\
2.1 \%\end{array}$ \\
\hline
\end{tabular}

$\dagger \mathrm{n}=1,500$ for each day

$\dagger \uparrow$ The total is not equal to $100 \%$ because of the missing tweets.

\section{CONCLUSION}

The ongoing COVID-19 pandemic has affected the entire world with reference to the economy, public health and the disruption of daily life. However, it has also highlighted the importance of the bi-directional flow of communication. Social media takes precedence over mainstream media for being the sum of the individuality of the masses, and for its ability to provide information without intermediaries, especially in times of crisis. Given this fact, this seven-day study analysed the reactions of Turkish Twitter users to the announcement of the first COVID-19 case in Turkey to glean some insights into the thought processes and ideas of individuals about their experience of the pandemic.

The study was primarily designed in consideration of the tendency of individuals to search for instant and unmediated information, as well as the human tendency to share ideas, feelings and experiences in times of crisis. The rise of new media and the spread of social media have made it easier to observe the instant reactions of individuals to such events. People express through social media networks in many ways, ranging from the sharing of personal opinions, emotions and information to demanding action from authorities and organisations. This study's finding that Turkish Twitter users most frequently posted their personal opinions (26\%) supports the founding argument of this study. According to the axiom postulated by Berger and Calabrese's study to make sense of human relations, uncertainty decreases as communication increases. In addition, their theorem emphasises that the quantum of communication and information seeking behaviours are inversely related (Berger \& Calabrese, 1975, pp. 101,102,107). The validity of their theory has been questioned by studies on digital media (Pratt et. al. 1999; Antheunis et. al. 2012)

This study posited three research questions. The research initiative was primarily undertaken to understand the initial reactions of Turkish Twitter users to the COVID-19 pandemic once the first positive case in Turkey was announced on 11 March 2020. Further, the study attempted to ascertain 
the dominant emotions of the tweets posted by Turkish users. It also sought to explore how these themes changed from day to day. The data analysis evinced that the initial reactions of Turkish Twitter users to the COVID-19 pandemic primarily comprised personal opinion (32\%), humour and sarcasm (30.5\%), and the expression of emotional states (14.1\%): these themes were most common on 11 March. In comparison, the most frequent themes in tweets posted on 17 March entailed requests and questions (37.6\%), personal opinions (26.5\%) and emotional states (19.5\%). The theme of personal opinion achieved the highest density on the first day and attained the second-highest concentration on the last day. The tool of social media converts one-way communication to interactive dialogue (Howell, 2015), and the fact that personal opinion was found to be the dominant theme on Twitter during the course of this study supports this interpretation.

One of the three research questions addressed the dominant emotions experienced by users during the onset of the pandemic. The results obtained by this study evidence that Turkish Twitter users posted about their emotional state (15.2\%), which was computed to be the fourth most common theme for the study. Health crises can affect people both physically and psychologically, and Twitter can be used to communicate both social and emotionally evaluative responses to health crises (McNeill, Harris \& Briggs, 2016, p. 11). Of the many codes representing the theme of the emotional state, three were prominent: aggression $(n=330)$, gratitude $(n=240)$ and concern $(n=200)$. The tweets included in the aggression code by researchers were generally reactive, insulting and written capitalised letters accompanied by aggressive punctuation. The code of gratitude was dominated by the articulation of respect and thanks toward healthcare workers and authorities. Finally, the concern code predominantly comprised tweets that expressed worry or uncertainty.

Another significant finding of the study in answer to its research questions involved irony $(11.1 \%)$ and jokes $(8.2 \%)$, which were found to be the most frequent and second most used codes under the theme of humour and sarcasm, regardless of theme's concentration on a particular day. The sample of this study could perhaps explain this outcome because the study sought to accentuate the initial reactions of the users and to note the change in the psychology of escape in times of crisis. The decline of the density of these codes after the first couple of days supports the first argument. On the other hand, Festinger's cognitive dissonance theory (1957) is worth examining in this context. The sarcastic language and unique jargon created via social media are other issues that could be highlighted in this context. This result reflects the social media discourse of creating jargon using digital ethnography and in a way, validates McLuhan's famous statement, 'the medium is the message' (1964).

The last significant finding of the study is that warning (5.9\%), suggestion (4.6\%) and demand (4.4\%) were the most extensively used codes under the theme of requests and questions. This outcome can be explained by the network society phenomenon, which is associated with the democratisation of communication channels. Individuals can voice their opinions on societal phenomena or other occurrences through messages posted on social media and thus attain the opportunity of exerting a transformative effect on the generally accepted views or influence the views of the majority. According to Manuell Castells, the Internet comprises decentralised communication networks (2016, p. 2). Van Dijk regards the environment that turns users into participants to be a prominent feature of the Internet, which is a democratic tool that in principle creates an equal platform for everyone (2016, p. 156). The spike in requests and question-related tweets on 17 March 2020 can, therefore, be interpreted as an indication that network communities can potentially perform significant roles in facilitating the public understanding of specific events in moments of crisis, and can function to form a public reasoning mechanism.

It is hoped that the findings of this study will enrich the domains of new media studies, cultural studies, medical sociology and health psychology. It is necessary to relate the findings of the study to these parallel scholarly disciplines. Some extant social media and health crises studies are also aligned with the pivotal findings of the current investigation. Some of these studies conducted over the last decade are paraphrased below in chronological order. Chew and Eysenbach (2010) used content analysis to investigate the use of Twitter during the 2009 H1N1 outbreak. In a similar vein,

Submit Date: 17.10.2020, Acceptance Date: 26.10.2020, DOI NO: 10.7456/11101100/002

Research Article - This article was checked by iThenticate

Copyright $($ T The Turkish Online Journal of Design, Art and Communication 
Liu and Kim (2011) studied the interactions between US health communicators via social and traditional media during the H1N1 pandemic, while Signorini, Segre and Polgreen (2011) focused on the use of Twitter to track levels of disease-related activities and public concern in the US during the H1N1 pandemic. Crook, et al. (2016) also utilised content analysis to analyse a live CDC Twitter chat during the 2014 Ebola outbreak. McNeill, Harris and Briggs (2016) described the influence of Twitter on vaccinations and antiviral drug uptakes in the UK during the 2009 H1N1 pandemic. Vos and Buckner (2016) focused on social media messages when bird flu was on the rise. Guidry et al. (2017), analysed Instagram and Twitter to achieve insights into the ways in which health organisations addressed the Ebola crisis. More recently, Reuter and Kaufhold (2018) conducted a retrospective review of 15 years of social media usage during emergencies and focused on future directions for crisis informatics. Finally, Rodin, Ghersetti and Odén (2019) evaluated the coverage of the 2014-2015 Ebola outbreak in news media and social media and assessed these in the light of public health crisis communication.

The limitations of the present study and recommendations for future researchers to overcome such limitations are listed below:

First, the tweets examined for this study emanated in the first week (11-17 March 2020) of the pandemic in Turkey. Perhaps this study took a narrow timeframe as a sample since the COVID-19 pandemic was covered extensively in news media even before it affected specific countries, and continues to affect the world. To eliminate the deficiencies arising from this limitation, future studies should focus on a different period in the interests of obtaining a more comprehensive understanding of people's reactions to the pandemic.

Second, the current investigation only addressed social media (and specifically, Twitter) users. Since social media, which includes Twitter, is already demographically and socio-culturally constrained, future studies on the subject should encompass different social strata.

Finally, the methodology of the research design, data collection and analysis techniques limit the findings of this study. The examination of diverse cultures, media tools or samples using different methods and techniques will enrich the findings obtained by this study.

The present study is nevertheless significant because it highlights the importance of social media and probes its features of information dissemination, experience sharing and the expression of emotions in the course of daily living as well as in times of crisis. The strengths of this research are vested in its methodological diversification and triangulation, its use of semi-statistics, its comprehensive data usage, data saturation, detailed explanations, the sufficiency in the number of coders and its determination of inter-coder reliability. This study contributes to the extant scholarship because it encapsulates the initial responses and reactions posted on Twitter on COVID-19 by a cultural base of subscribers. This study also accords an understanding of how a global health crisis is reflected in everyday language. Future studies could examine diverse social media platforms in different cultures to bridge the extant research gaps.

\section{REFERENCES}

Almond, D. (2006). Is the 1918 influenza pandemic over? Long-term effects of In Utero influenza exposure in the post-1940 U.S. population. Journal of Political Economy, 114(4), 672-712.

Antheunis, M. L. Schouten, A. P. Valkenburg, P. M. \& Peter, J. (2012). Interactive uncertainty reduction strategies and verbal affection in computer-mediated communication. Communication Research, 39(6), 757-780. doi: 10.1177/0093650211410420.

Austin, L., Fisher Liu, B., \& Jin, Y. (2012). How audiences seek out crisis information: Exploring the social-mediated crisis communication model. Journal of Applied Communication Research, 40(2), 188-207.

Aziz, A. (2014). Sosyal bilimlerde araştırma yöntemleri ve teknikleri (9th ed.). Ankara: Nobel Akademik Yayıncılık.

Research Article - This article was checked by iThenticate 
Bazarova, N. N., \& Choi, Y. H. (2014). Self-disclosure in social media: Extending the functional approach to disclosure motivations and characteristics on social network sites. Journal of Communication, 64, 635-657.

Bazarova, N. N., Taft, J.G., Choi, Y.H., \& Cosley, D. (2012). Managing 1mpressions and relationships on Facebook: self-presentational and relational concerns revealed through the analysis of language style. Journal of Language and Social Psychology, 32(2), 121-141.

Barrett, L. F. (2006). Solving the emotion paradox: categorization and the experience of emotion. Personality, and Social Psychology Review, 10(1), 20 - 46.

Berger, C. R., \& Calabrese, R. J. (1975). Some explorations in initial interaction and beyond: toward a developmental theory of interpersonal communication. Human Communication Research, 1(2), 99112, doi: 10.1111/j.1468-2958.1975.tb00258.x.

Beyens, I., Frison, E., \& Eggermont, S. (2016). "I don't want to miss a thing": Adolescents' fear of missing out and its relationship to adolescents' social needs, Facebook use, and Facebook related stress, Computers in Human Behavior, 64:1(8),1-32, doi: 10.1016/j.chb.2016.05.083.

Blackwell, D., Leaman, C., Tramposch, R., Osborne, C., \& Liss, M. (2017). Extraversion, neuroticism, attachment style and fear of missing out as predictors of social media use and addiction. Personality And Individual Differences, 116, 69-72.

Brooks, F. J. (1993). Revising the conquest of Mexico: smallpox, sources, and populations. The Journal of Interdisciplinary History, 24(1):1-29.

Bruns, A., \& Stieglitz, S. (2012). Quantitative approaches to comparing communication patterns on Twitter. Journal of Technology in Human Services, 30(3-4), 160-185.

Boin, A., Hart, P., Stern, E., \& Sundelius, B. (2005). The politics of crisis management: Public leadership under pressure. New York: Cambridge University Press.

Boin, A., Rhinard, M., \& Ekengren, M. (2014). Managing transboundary crises: The emergence of European Union capacity, Journal of Contingencies and Crisis Management, 22(3), 130- 142.

Bollen, J., Mao, H., \& Pepe, A. (2011). Modeling public mood and emotion: Twitter sentiment and socio-economic phenomena. In Fifth International AAAI Conference on Weblogs and Social Media.

Bortee, D., \& Seltzer, T. (2009). Dialogic strategies and outcomes: An analysis of environmental advocacy groups' Facebook profiles, Public Relations Review, 35(3), 317 - 319.

Burgess, J., \& Bruns, A. (2012). Twitter archives and the challenges of" Big Social Data" for media and communication research. M/C Journal, 15(5).

Castells, M. (2016). İletişim gücü. İstanbul: İstanbul Bilgi Üniversitesi.

Cheng, S. T., \& Siankam, B. (2009). The impacts of the HIV/AIDS pandemic and socioeconomic development on the living arrangements of older persons in Sub-saharan Africa: A country-level analysis, Am J Community Psychol, 44, 136-147, doi: 10.1007/s10464-009-9243-y.

Chew, C., \& Eysenbach, G. (2010). Pandemics in the age of Twitter: content analysis of Tweets during the 2009 H1N1 outbreak. PloS one, 5(11).

Choi, Y., \& Lin, Y. H. (2009). Consumer responses to Mattel product recalls posted on online bulletin boards: Exploring two types of emotion. Journal of Public Relations Research, 21(2), 198-207.

Crook, B., Glowacki, E. M., Suran, M., K. Harris, J., \& Bernhardt, J. M. (2016). Content analysis of a live CDC Twitter chat during the 2014 Ebola outbreak. Communication Research Reports, 33(4), 349355. 
Falkheimer, J. (2013). Transboundary and cultural crisis communication, (ed.) Handbuch Krisenmanagement. Wiesbaden: Springer Fachmedien Wiesbaden, Pp. 211-225.

Festinger, L. (1957). A theory of cognitive dissonance. California: Stanford University Press.

Fleiss, J. L. (1971). Measuring nominal scale agreement among many raters. Psychological Bulletin, 76, 378-382.

Fraustino, J. D., Liu, B., \& Jin, Y. (2012). Social media use during disasters: a review of the knowledge base and gaps, Final Report to Human Factors/Behavioral Sciences Division, Science and Technology Directorate, U.S. Department of Homeland Security. College Park, MD: START.

Gasparini, R. Amicizia D. Lai, P. L., \& Panatto, D. (2012). Clinical and socioeconomic impact of seasonal and pandemic influenza in adults and the elderly, Human Vaccines \& Immunotherapeutics, 8(1), 21-28, doi: 10.4161/hv.8.1.17622

Gerlitz, C., \& Rieder, B. (2013). Mining one percent of Twitter: Collections, baselines, sampling. M/C Journal, 16(2).

Griffiths, M. D. (2012). Facebook addiction: Concerns, criticisms, and recommendations. Psychological Reports, 110, 518-520.

Gottfried, J., \& Shearer, E. (2016) News use across social media platforms 2016. Pew Research Center. Retrieved from http://www.journalism.org/2016/05/26/news-use-across-social-mediaplatforms-2016/. Access Date: 05.05.2020.

Guidry, J. P., Jin, Y., Orr, C. A., Messner, M., \& Meganck, S. (2017). Ebola on Instagram and Twitter: How health organizations address the health crisis in their social media engagement. Public Relations Review, 43(3), 477-486.

Han, M. C., \& Kim, Y. (2016). Can social networking sites be e-commerce platforms?. Pan-Pacific Journal of Business Research, 7(1), 24-39.

Hays, N. J. (2005). Epidemics and pandemics their 1mpacts of human history, ABC CLIO, Oxford, England.

Hogan, B., Quan-Haase, A. (2010). Persistence and change in social media. Bulletin of Science, Technology and Society, 30(5), 309-315.

Hosseini, P. Sokolow, S. H. Vandegrift, K. J. Kilpatrick, A. M., \& Daszak, P. (2010). Predictive power of air travel and socio-economic data for early pandemic spread, PLoS One. 5(9): e12763, DOI: 10.1371/journal.pone.0012763.

Howell, G. (2015). MH370 all lives lost : the 'Black Swan' disaster confirmed with a 26 word txt. Asia Pacific Public Relations Journal, 16(1), 8-21.

Hughes, A. L., \& Palen, L. (2009). Twitter adoption and use in mass convergence and emergency events. International Journal of Emergency Management, 6(3-4), 248-260.

Kim, K.S., Sin, S., C. J., \& Tsai, T. I. (2014). Individual differences in social media use for information seeking. The Journal of Academic Librarianship, 40, 171-178. doi: 10.1016/j.acalib.2014.03.001.

Kirtiş, A. K., \& Karahan, F. (2011). To be or not to be in social media arena as the most cost-efficient marketing strategy after the global recession. Procedia-Social and Behavioral Sciences, 24, 260268.

Kraut, R., Patterson, M., Landmark, V., Kiesler, S., Mukophadhyay, T., \& Scherlis, W. (1998) Internet paradox: A social technology that reduces social involvement and psychological well being?, American Psychologist, 53, 1017-1031. 
Kushin, M. J. (2010). Tweeting the issues in the age of social media? Intermediaagenda setting between the "New York Times" and Twitter. Washington State University.

Kuss, D. J., Griffiths, \& M. D. (2011). Online social networking and addiction - A review of the psychological literature. International Journal of Environmental Research and Public Health, 8, 35283552 .

Landis, J.R., \& Koch, G.G. (1977). The measurement of observer agreement for categorical data. Biometrics, 33, 159-174.

Laerd Statistics (2019). Fleiss' kappa using SPSS Statistics. Statistical tutorials and software guides. Retrieved 04.12.20, from https://statistics.laerd.com/spss-tutorials/fleiss-kappa-in-spss-statistics.php.

Li, Q. Med, M. Guan, X. Wu, P. Wang, X. Zhou, L...\& Feng, Z. (2020). Early transmission dynamics in Wuhan, China, of novel coronavirus-1nfected pneumonia, The New England Journal of Medicine, 382(13):1199-1207. doi: 10.1056/NEJMoa2001316.

Liu, B. F., Fraustino, J. D., \& Jin, Y. (2016). Social media use during disasters: How information form and source influence intended behavioral responses, Communication Research, 43(5), 626 - 646.

Liu, B. F., \& Kim, S. (2011). How organizations framed the 2009 H1N1 pandemic via social and traditional media: Implications for US health communicators. Public Relations Review, 37(3), 233 244.

Lombard, M., Snyder-Duch, J., \& Bracken, C. C. (2002). Content analysis in mass communication: Assessment and reporting of intercoder reliability. Human Communication Research, 28(4), 587-604.

Lynch, O. H. (2002). Humorous communication: Finding a place for humor in communication research. Communication Theory, 12(4), 423-445.

McNeill, A., Harris, P. R., \& Briggs, P. (2016). Twitter influence on UK vaccination and antiviral uptake during the 2009 H1N1 pandemic. Frontiers in Public Health, 4, 26.

McLuhan, M., \& Lapham L. H. (1994). Understanding Media: The Extensions of Man. London: The MIT Press.

Mehta, P. McAuley, D. F. Brown, M. Sanchez, E. Tattersall, R. S., \& Manson, J. J. (2020). COVID19: Consider cytokine storm syndromes and immunosuppression, The Lancet, 395, 10.229. doi: 10.1016/S0140-6736(20)30628.

Melek, G. (2015). Medya arası gündem belirleme kuramı çerçevesinde hürriyet ve twitter üzerinde bir çalışma (Unpublished doctoral thesis). T.C. Ege Üniversitesi.

Mills, A., Chen, R., Lee, J., \& Raghav Rao, H. (2009). Web 2.0 emergency applications: How useful can Twitter be for emergency response? Journal of Information Privacy and Security, 5(3), 3-26.

Merriam, S. B. (2013). Nitel araştırma: Desen ve uygulama için bir rehber. (Sellahattin Turan, Trans.). Ankara: Nobel Yayın Dağıtım.

Olsson, E. (2015) Transboundary crisis networks: The challenge of coordination in the face of global threats. Risk Management, 17(2), 91-108.

Parveen, F., Jaafar, N. I., \& Ainin, S. (2015). Social media usage and organizational performance: Reflections of Malaysian social media managers. Telematics and informatics, 32(1), 67-78.

Patton, M. Q. (1999). Enhancing the quality and credibility of qualitative analysis. HSR: Health Service Research, 34:5 Part II.

Polimeni, J., \& Reiss, J. P. (2006). The first joke: Exploring the evolutionary origins of humor. Evolutionary Psychology, 4(1), 347-366. 
Pratt, L. Wiseman R. L. Cody, J. M., \& Wendt, P. F. (1999). Interrogative strategies and information exchange in computer-mediated communication. Communication Quarterly, 47(1):46-66, doi: 10.1080/01463379909370123.

Procopio, C. H., \& Procopio, S. T. (2007). Do you know what it means to miss New Orleans? Internet communication, geographic community, and social capital in crisis. Journal of Applied Communication Research, 35(1), 67-87.

Przybylski, A. K., Murayama, K., DeHaan, C. R.,\& Gladwell, V. (2013). Motivational, emotional, and behavioral correlates of fear of missing out. Computers in Human Behavior, 29(4), 1841-1848.

Rajdev, M., \& Lee, K. (2015). Fake and spam messages: Detecting misinformation during natural disasters on social media. In 2015 IEEE/WIC/ACM International Conference on Web Intelligence and Intelligent Agent Technology (WI- $\quad$ IAT) (Vol. 1, pp. 17-20). IEEE.

Reuter, C., \& Kaufhold, M. A. (2018). Fifteen years of social media in emergencies: a retrospective review and future directions for crisis informatics. Journal of Contingencies and Crisis Management, 26(1), 41-57.

Rime, B. (2009). Emotion elicits the social sharing of emotion: Theory and empirical review. Emotional Review, doi: 10.1177/1754073908097189.

Rime, B., Paez, D., Kanyangara, P., \& Yzerbyt, V. (2011). The social sharing of emotions in interpersonal and in collective situations: Common psychosocial consequences. (Eds.) Emotion regulation and well-being, New-York: Springer, 147-164.

Rodin, P., Ghersetti, M., \& Odén, T. (2019). Disentangling rhetorical subarenas of public health crisis communication: A study of the 2014-2015 Ebola outbreak in the news media and social media in Sweden. Journal of Contingencies and Crisis Management, 27(3), 237-246.

Ruderman, C. Tracy, C. S. Bensimon, C. M. Bernstein, M. Hawryluck, N. Shaul, R... \& Upshur, R. EG. (2006). On pandemics and the duty to care: Whose duty? Who cares?. BMC Medical Ethics, 7(5)1-6. doi:10.1186/1472-6939-7-5.

Ruggiero, A., \& Vos, M. (2014). Social media monitoring for crisis communication: Process, methods, and trends in the scientific literature. Online Journal of Communication and Media Technologies, 4(1), 105-130.

Rutter, P. D. Mytton, O. T. Mak, M., \& Donaldson, L. J. (2012). Socio-economic disparities in mortality due to pandemic influenza in England. Int J Public Health, 57, 745-750 doi:10.1007/s00038012-0337-1.

Rybalko, S., \& Seltzer, T. (2010). Dialogic communication in 140 characters or less: How Fortune 500 companies engage stakeholders using Twitter. Public Relations Review, 36, 336-341.

Sanders, C., Field, T., Diego, M., \& Kaplan, M. (2000). The relationship of Internet use to depression and social 1solation among adolescents. Adolescence, 35, 237-242.

Schultz, F., Utz, S., \& Göritz, A. (2011). Is the medium the message? Perceptions of and reactions to crisis communication via Twitter, blogs, and traditional media. Public Relations Review, 37(1), 2027.

Shifman, L. (2007). Humor in the age of digital reproduction: Continuity and change in internetbased comic texts. International Journal of Communication, 1(1), 187-209.

Shifman, L., Levy, H., \& Thelwall, M. (2014). Internet jokes: The secret agents of globalization?. Journal of Computer-Mediated Communication, 19(4), 727-743.

Signorini, A., Segre, A. M., \& Polgreen, P. M. (2011). The use of Twitter to track levels of disease activity and public concern in the US during the influenza A H1N1 pandemic. PloS one, 6(5). 
Sreenivasan, N. D., Lee, C. S., \& Goh, D. H. L. (2011). Tweet me home: Exploring information use on Twitter in crisis situations. In International Conference on Online Communities and Social Computing (120-129). Springer, Berlin, Heidelberg.

Stellefson, M., Chaney, B., Ochipa, K., Chaney, D., Haider, Z., Hanik, B., ... \& Bernhardt, J. M. (2014). YouTube as a source of chronic obstructive pulmonary disease patient education: a social media content analysis. Chronic Respiratory Disease, 11(2), 61-71.

Stieglitz, S., \& Dang-Xuan, L. (2013). Emotions and information diffusion in social media-sentiment of microblogs and sharing behavior. Journal of Management Information

Systems, 29(4), 217248.

Sung, M., \& Hwang, J. S. (2014). Who drives a crisis? The diffusion of an issue through social networks. Computers in Human Behavior, 36, 246-257.

Taylor, M., Kent, M. L., \& White, W. J. (2001). How activist organizations are using the internet to build relationships. Public Relations Review, 27(3), 263-284.

Taylor, M., \& Perry, D.C. (2005). Diffusion of traditional and new media tactics İn crisis communication, Public Relations Review, 31(2), 209-217.

The World Bank (2018). Primary completion rate, total (\% of relevant age group) - Sub-Saharan Africa. Retrieved from https://data.worldbank.org/indicator/SE.PRM.CMPT.ZS?locations=ZG. Access Date: 13.05.2020.

Twitter FQA, Retrieved from https://developer.twitter.com/en/docs/labs/filtered-stream/faq. Access Date: 13.05.2020.

Ural, A., \& K1lıç, İ. (2013). Bilimsel araştırma süreci ve spss ile veri analizi (4th edition). Ankara: Detay Yayıncilik.

Van Dijk, J. (2016). A $\breve{g}$ toplumu. İstanbul: Kafka.

Veil, S. R., Buehner, T., \& Palenchar, M. J. (2011). A work-in-process literature review: Incorporating social media in risk and crisis communication. Journal of Contingencies and Crisis Management, 19(2), 110-122.

Vos, S. C., \& Buckner, M. M. (2016). Social media messages in an emerging health crisis: tweeting bird flu. Journal of Health Communication, 21(3), 301-308.

Wang, B., \& Zhuang, J. (2017). Crisis information distribution on Twitter: a content analysis of tweets during Hurricane Sandy. Natural Hazards, 89(1), 161-181.

Whittemore, R., Chase, S. K., \& Mandle, C. L. (2001). Validity in qualitative research. Qualitative Health Research, 11(4), 522-537.

Wildemuth, B. M. (2009). Applications of social research methods to questions in information and library science. London: Libraries Unlimited.

World Health Organization (WHO). Q\&A on coronaviruses (COVID-19). Retrieved from who.int/emergencies/diseases/novel-coronavirus-2019/question-and-answers-hub/q-a-detail/q-acoronaviruses. Access Date: 10.05.20.

Wright, D. K., \& Hinson, M. D. (2009). An updated look at the impact of social media on public relations practice, Public Relations Journal, 3(2), 1- 27.

Yıldırım, A., \& Şimşek, H. (2016). Sosyal bilimlerde nitel araştırma yöntemleri (10th edition). Ankara: Seçkin Yayınc1lı.

Zafar, M. B., Bhattacharya, P., Ganguly, N., Gummadi, K. P., \& Ghosh, S. (2015). Sampling content from online social networks: Comparing random vs. expert sampling of the twitter stream. ACM Transactions on the Web (TWEB), 9(3), 1-33. 
The Turkish Online Journal of Design, Art and Communication - TOJDAC

ISSN: 2146-5193, January 2021 Volume 11 Issue 1, p.20-41

Zaki, J., \& Williams, W. J. (2013) Interpersonal emotion regulation, Emotion, 13(5), 803 - 810.

Acknowledgement: We are grateful to Ege University Planning and Monitoring Coordination of Organizational Development and Directorate of Library and Documantaion for their support in editing and proofreading service of this study. 